\title{
Introduktion
}

\section{Norrköpingsredaktionen välkomnar till ett nytt år med Socialvetenskaplig tidskrift}

Välkomna till nummer 1, 2020 av Socialvetenskaplig tidskrift, det första numret utgivet av den nya redaktionen vid Linköpings universitet. Vi är mycket glada över att ha fått förtroendet att ge ut tidskriften under de närmaste fem åren och på så vis förvalta det nyligen 25-årsjubilerande forumet för en bred socialvetenskaplig diskussion. Vi ser uppdraget som både ärofullt och viktigt, inte minst med tanke på betydelsen av att värna utgivningen av vetenskapliga tidskrifter av hög kvalitet på svenska.

Vi gläds över de många manus som kommer in till tidskriften. Det visar om något på tidskriftens aktualitet och fortsatta betydelse för det breda socialvetenskapliga ämnesområdet. Tillströmningen av manus innebär även att det fanns en rad redan accepterade texter när vi tog över tidskriften. Därför består detta första nummer också av bidrag som är färdiggranskade av den föregående redaktionen vid Socialhögskolan och Lunds universitet. Artiklarna spänner över ett brett fält av socialvetenskapliga frågor, teorier och metoder.

I den första artikeln av Anna-Karin Larsson undersöks förändring och stabilitet i synen på barns och ungas psykiska hälsa så som den speglats i Läkartidningen 1970-2017. Larsson analyserar hur den medicinska kunskapen relateras till den historiska kontexten samt hur densamma interagerat med andra politiska och samhälleliga diskurser. I den andra artikeln, som också handlar om unga, analyserar Jessica Arvidsson, Carin Staland-Nyman, Stephen Widén och Magnus Tideman sambanden mellan sysselsättning för unga vuxna med intellektuell funktionsnedsättning som gått i gymnasiesärskolan och deras sociala bakgrund, här mätt med föräldrarnas utbildningsnivå och geografiska härkomst. Den följs av en artikel som precis som Larsson analyserar texter, där Fanny Edenroth Cato analyserat subjektsformeringar i de barnböcker som berättar om erfarenheter av att ha en neuropsykiatrisk diagnos eller att vara högkänslig. Nästa artikel handlar om vuxen- 
psykiatrisk verksamhet. Veikko Pelto-Piri, Ulrika Hylén och Lars Kjellin har intervjuat psykiatripersonal och undersökt förekomst och former av informellt tvång i psykiatrin. Med informellt tvång menas här de former av tvångsåtgärder som används i psykiatrisk verksamhet men som inte regleras av lagstiftningen. I den sista artikeln, som handlar om argument för och emot förenklad biståndshandläggning, undersöker Anna Siverskog och Håkan Jönson hur företrädare för svensk socialtjänst ser på tillhandahållandet av individuella hemtjänstinsatser till äldre som sker med hänvisning till ålder men utan individuell bedömning av behov.

Vid den nya redaktionens tillträde efter årsskiftet nåddes vi tyvärr av beskedet att en av redaktionens medlemmar allvarligt insjuknat. Till vår sorg måste vi meddela att Kerstin Johansson, biträdande professor i socialt arbete vid Linköpings universitet, lämnat oss under våren. Vi avslutar därför detta första nummer med ett minnesord för Kerstin.

Den nya redaktionen är sammansatt för att tillgodose en bred ämnesmässig och disciplinär kompetens och med förankring i flera av de forskningsmiljöer vid Linköpings universitet som ägnar sig åt forskning inom det socialvetenskapliga fältet. Flera av miljöerna är formade av tvär- eller mångvetenskapliga perspektiv, $i$ enlighet med en tradition som kännetecknar en stor del av den forskning som bedrivs vid Linköpings universitet. I redaktionen finns alltså en stor bredd, inte minst vad gäller disciplinär bakgrund. Inom redaktionen ryms bakgrunder inom socialt arbete, ekonomisk historia, sociologi, statsvetenskap, historia, juridik, rättssociologi och psykologi. Flertalet av dem som ingår i redaktionen har även disputerat eller varit verksamma i tvärvetenskapliga sammanhang däribland etnicitet och migration, mänskliga rättigheter, barn, välfärdsrätt, äldre och åldrande. I redaktionen finns dessutom en bred spännvidd vad gäller kompetens inom olika ämnesområden och empiriska fält (som arbetsliv, offentlig förvaltning, organisering av välfärd, rehabilitering, rättslig reglering, utbildning, socialt arbete, vård och omsorg), förtrogenhet med olika slags forskningsmetoder (från olika varianter av kvalitativa mikrostudier till kvantitativa registerstudier) och sist men inte minst, intresse för en mångfald av kategoriseringsgrunder som är relevanta för ett socialvetenskapligt forskningssammanhang (t.ex. kön, klass, etnicitet/ras, ålder, generation, funktion).

Redaktionens ambition är att verka för att tidskriften under de kommande fem åren ska rymma både den bredd och det djup som finns i forskningen inom det socialvetenskapliga fältet. Vi vill bidra till en livaktig diskussion om aktuella frågor och teman, inte minst om vad socialvetenskap kan handla om. Vad är det för slags frågeställningar som är rimliga och möjliga att ställa? Vilka ansatser, teorier och metoder kan användas? Mötet mellan teorier, metoder och disciplinära traditioner är här en styrka eller rentav en nödvändighet, just därför att det i denna dialog 
skapas en dynamik som både utmanar och stärker en socialvetenskaplig kärna. Om något så vill vi bidra till en sådan dialog, och just här ser vi att den tvärvetenskapliga tradition som är stark vid just Linköpings universitet kan vara ett viktigt avstamp. Ett sätt att bidra till dialogen är att arbeta aktivt med temanummer. Ett första temanummer är under arbete och kommer att ges ut som ett dubbelnummer mot slutet av året, på temat kritiska sociala arbeten.

Med de orden välkomnar vi er alla till fem spännande år fyllda av bred socialvetenskaplig diskussion.

Karin Osvaldsson Cromdal, korresponderande redaktör

Magnus Dahlstedt, ansvarig utgivare 